\title{
The new MD General Medicine Training Program to face challenges and opportunities of the twenty-first century
}

\author{
Jayasinghe $\mathbf{S}^{1}$, De Silva $\mathbf{S}^{1}$, Karunanayake $\mathbf{P}^{1}$ \\ Journal of the Ceylon College of Physicians, 2017, 48, 50-57
}

\section{Introduction}

The MD (General Medicine) program is Sri Lanka's first, and currently only, postgraduate program that trains specialists in General ('Internal') Medicine. It had its origin in 1959 as the MD (Ceylon), offered by the Department of Medicine, Faculty of Medicine, University of Colombo and a brainchild of Professor Kumaradasa Rajasuriya. It was the first postgraduate degree in the medical profession in our country, and was initially offered directly following an examination modelled after the MD (London) and the MRCP (London). It soon achieved international recognition ${ }^{1}$. With the establishment in 1980 of the Postgraduate Institute of Medicine (PGIM), University of Colombo, it was brought under its purview and became $\mathrm{MD}$ (Colombo), organized and delivered by the Board of Study in Medicine (BOS). A formal, in-service training program was added soon after, and this has undergone periodic revision to suit changing times. The Mission Statement of the PGIM pledges to "...plan, implement, monitor and evaluate postgraduate academic programs required to produce specialists of the highest quality, competence and dedication, in order to provide optimum humane health care to the people of Sri Lanka..."2.

In 2010 the BOS decided to review the program to take account of the many changes that have taken place both locally and globally and to meet the challenges of the $21^{\text {st }}$ century. The new Prospectus, which was produced following widespread discussion, was approved by the University of Colombo in January 2016, and the first batch of trainees was recruited at the new Selection Examination in Medicine (SEM) in April-May 2016 and commenced their training in July 2016. They will be sitting their MD Examination in the first quarter of 2019 , and the first lot of new specialists in General Medicine could receive their board certification starting in the first quarter of 2021. Until then the old and new prospectuses will exist side by side, but thereafter the

\footnotetext{
${ }^{1}$ Curriculum Implementation Subcommittee, Board of Study in Medicine, Postgraduate Institute of Medicine, University of Colombo.

Corresponding author: Karunanayake P

E-mail: pandukaru@hotmail.com
}

old prospectus will gradually phase out, as the remaining trainees recruited before July 2016 complete their stint at the PGIM.

The BOS considers the Ceylon College of Physicians (CCP) as one of its most important partners in the delivery of the MD General Medicine program. Towards this end, two of its members are nominated directly by the Council of the CCP. The purpose of this article is to apprise the members of the CCP about the new Prospectus and the challenges and opportunities it offers, as we face the important, complex and evolving task of producing MD doctorates and board-certified general physicians for the people of Sri Lanka in the $21^{\text {st }}$ century.

\section{Developing the new Program}

The task of developing the new Program was entrusted by the BOS to a committee in 2010. Its specific terms of reference were to present recommendations on the the 'final product' (i.e. the type of general physician who would meet the needs of the $21^{\text {st }}$ century) and the basic structure of the training program and its components (including objectives, methods and duration of each component and its assessment) necessary to achieve this.

A preliminary workshop was held in December 2010 to explore some of the issues and produce a concept paper that would capture the crucial elements of a program for "Training Physicians for the $21^{\text {st }}$ Century". The group decided on a variation of an 'outcome-based approach' (i.e. to identify outcomes expected of the specialist and 'work backwards' to identify elements of a training program that would achieve the desired competencies, objectives or outcomes ${ }^{3,4}$. However, the term 'objectives' was preferred over 'outcomes' for the discussions, because of better familiarity of the trainers and trainees to this term. The approach to anchor the curriculum on objectives was a deliberate attempt to think afresh, in contrast to identifying weaknesses of the existing program and attempting to improve it by 'tinkering' with it. The framework agreed to by the group was to derive the contents, educational methods, and assessments in the curriculum (Figure) ${ }^{5}$. This enabled a more comprehensive view of the curriculum. 


\section{Figure. Framework used to derive the teaching/ learning program}

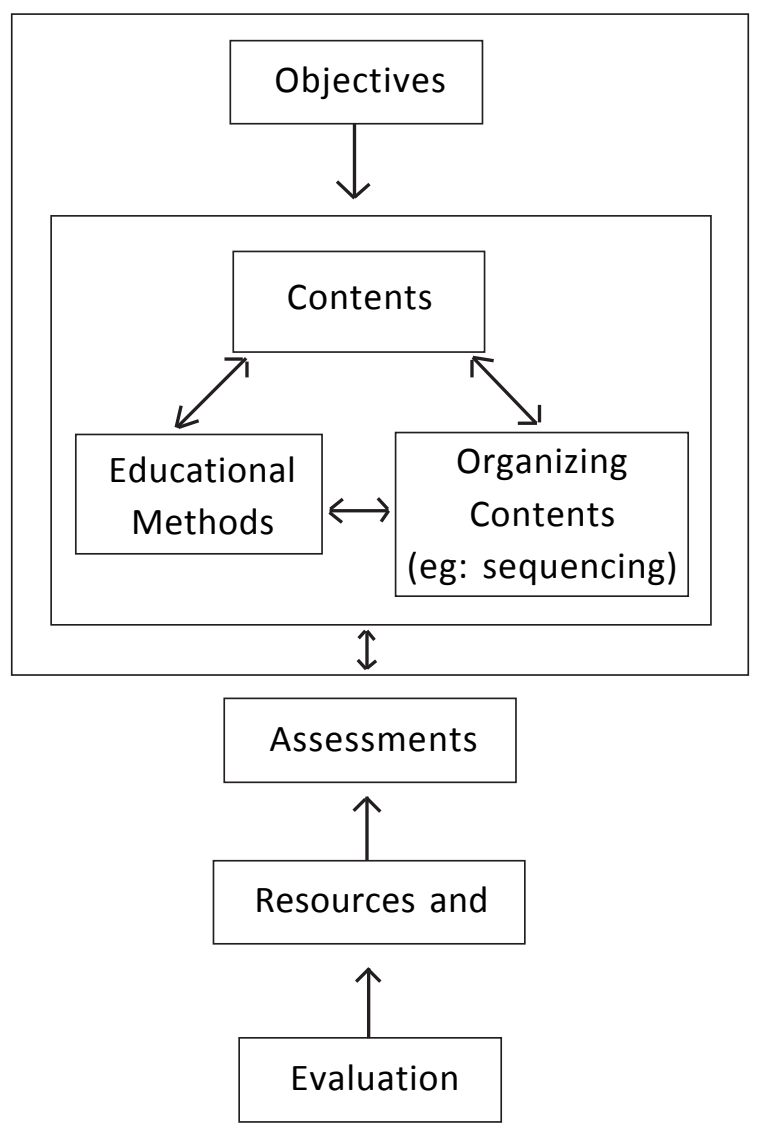

The committee held ten formal meetings and numerous e-mail discussions over almost $2 \frac{1}{2}$ years. Some issues were further discussed during the monthly BOS meetings.

The key issue in this approach was to identify objectives for the training program. These were developed using the following information:

- $\quad$ Feedback from trainers (both local and overseas), trainees and examiners. We obtained feedback from trainers and trainees using an anonymized postal questionnaire. Questionnaires were sent to 70 trainers, of whom 39 (55.7\%) responded, and to 200 trainees (at both pre-MD and post-MD levels), of whom 27 (13.5\%) responded. Reports submitted by overseas trainers (foreign supervisors) and MD examiners were also perused for significant comments.

- Report of a previous Workshop Report on curriculum review organized by the BOS and held in 2004 (unpublished document).

- Review of training programs in selected countries: UK, Australia, USA, Singapore and Malaysia.
- $\quad$ Existing objectives of the Medicine program, as per the PGIM prospectus.

- Extrapolating the needs of physicians in future (see Table 1$)^{6}$.

The draft developed in this manner was further discussed at the BOS and amended. It was thereafter presented at a one-day workshop to which all trainers were invited. This workshop included presentations on programs in other countries, principles of education and training, and the results from feedback. Suggestions from this workshop were further incorporated to the draft, and the program and Prospectus finalized by the BOS. It was thereafter submitted for approval sequentially through the Academic Affairs, Accreditation, Examinations and Discipline Committee (PGIM); the Board of Management (PGIM); and the Senate, the Legislative Committee and the Council of the University of Colombo, finally becoming approved in January 2016 and 'going online' in the public domain thereafter. (To download it from the PGIM website, go to http://pgim.cmb.ac.Ik/?page_id=704 and under "MD Medicine", click on "Amendment 2016".)

\section{What is new?}

The new proposal begins with a preamble that defines a General Physician: "General physicians are those with expertise in the diagnosis and management of acute and complex, chronic and multisystem disorders in adult patients. They undertake a comprehensive assessment of a patient's problems, both biomedical and psychosocial. They are competent to provide coordinated care with the assistance of multidisciplinary teams to optimize health outcomes while working in hospitals and clinics".

Other competencies required to be ideal physicians to serve in the $21^{\text {st }}$ century that are included in the document include a scientific approach with in-depth and broad knowledge, a teacher, a health advocate, and the ability to work in close collaboration with specialists in finer specialties.

The Mission was "To develop a physician competent in providing effective care while being sensitive to human needs". Objectives were given in four domains: Clinical, Professionalism, Management and 'Other' diverse domains.

The tables 2-6 compare and contrast the salient points in the new training program with the old program. The changes are arranged under SEM (Table 2), General Medicine registrar training (Table 3), finer specialties registrar training (Table 4), the MD Examination (Table 5 ), and senior registrar training in General Medicine (both local and overseas) (Table 6). 
Table 1. Elements of a framework, examples of issues and competencies

\begin{tabular}{|c|c|c|c|}
\hline $\begin{array}{l}\text { Factors that } \\
\text { may change }\end{array}$ & \multicolumn{2}{|c|}{ Examples of changing scenarios } & $\begin{array}{l}\text { Competencies required to meet the } \\
\text { changing scenarios }\end{array}$ \\
\hline Health System & $\begin{array}{l}\text { a) } \\
\text { b) } \\
\text { c) } \\
\text { d) }\end{array}$ & $\begin{array}{l}\text { Growth of private sector, ambulatory } \\
\text { care, screening for prevention } \\
\text { Growth of health insurance } \\
\text { Demand for other health systems } \\
\text { Introduction of IT based method } \\
\text { (e.g. telemedicine, 'paperless' } \\
\text { hospitals) } \\
\text { empowerment of other professional } \\
\text { groups } \\
\text { (e.g. physiotherapists, nurses) }\end{array}$ & $\begin{array}{l}\text { 1. Ability to work in diverse settings: home- } \\
\text { based, community-based, work-place, } \\
\text { insurance } \\
\text { 2. IT skills } \\
\text { 3. Leadership and team-work and clinical } \\
\text { governance }\end{array}$ \\
\hline Technology & $\begin{array}{l}\text { a) } \\
\text { b) } \\
\text { c) } \\
\text { d) } \\
\text { e) } \\
\text { f) } \\
\text { g) }\end{array}$ & $\begin{array}{l}\text { Nano-technology } \\
\text { (nano-toxicology, nano-medicine) } \\
\text { Regenerative medicine } \\
\text { and genomics } \\
\text { Newer instruments } \\
\text { (e.g. endoscopies) } \\
\text { Transplantation } \\
\text { Drug innovations }\end{array}$ & $\begin{array}{l}\text { 1. Basic skills and knowledge } \\
\text { 2. Acquire generic skills where relevant } \\
\text { 3. Respond to emerging ethical issues }\end{array}$ \\
\hline
\end{tabular}

\begin{tabular}{|c|c|c|}
\hline Health & a) & Chronic diseases \\
\hline transitions & b) & Older population \\
\hline and global & c) & Travel medicine \\
\hline changes & d) & $\begin{array}{l}\text { Effects of climate change on } \\
\text { health }\end{array}$ \\
\hline
\end{tabular}

1. Clinical skills in diseases prevention and screening

2. Team-work to tackle chronic diseases

3. Basic knowledge in relation to climate change, travel medicine and emerging diseases

$\begin{array}{llll}\begin{array}{l}\text { Growth of } \\ \text { knowledge }\end{array} & \text { a) Exponential growth of knowledge } & \begin{array}{l}\text { 1. Ability to seek, access, appraise, } \\ \text { b) Current knowledge gets out-of-date }\end{array} & \begin{array}{l}\text { 2. Self-directed learning skills } \\ \text { rapidly }\end{array} \\ & \begin{array}{l}\text { 3. Generation of knowledge and } \\ \text { innovations }\end{array}\end{array}$

Globalization Physicians working across borders

Ability to work globally and in different work environments
Patient
expectations
a) Knowledgeable and empowered patient groups
b) Potential for conflicts and litigation

1. Communication skills, ethical reasoning and accountability

2. Knowledge of medical law

\section{Social and cultural}

a) Marginalization of population groups

b) Continuing poverty and health inequalities
1. Care of the poor and marginalized

2. Knowledge on access to social services and support 
Table 2. Selection Examination in Medicine (SEM)

\begin{tabular}{|c|c|c|}
\hline Component & Current training programme & Proposed training programme \\
\hline 1. Objectives & & $\begin{array}{l}\text { Categorized according to four } \\
\text { domains: Clinical, Professionalism, } \\
\text { Management and Other }\end{array}$ \\
\hline $\begin{array}{l}\text { 2. Entry to training } \\
\text { programme }\end{array}$ & Detailed curriculum not available & $\begin{array}{l}\text { Detailed curriculum will be available to } \\
\text { potential candidates and paper will be } \\
\text { blue-printed }\end{array}$ \\
\hline \multicolumn{3}{|l|}{ 3. Entry examination } \\
\hline \multirow{2}{*}{$\begin{array}{l}\text { Multiple choice } \\
\text { questions (TI } \\
\text { F=true/false type } \\
\text { and }\end{array}$} & \multirow{2}{*}{$\begin{array}{l}\text { T/F ( } 60 \text { in } 2 \frac{1}{2} \text { hours): approx. } \\
2 / 3 \text { on General Medicine and } \\
1 / 3 \text { on Basic Sciences }\end{array}$} & $\begin{array}{l}\text { To be blue printed, preferably based } \\
\text { on systems }\end{array}$ \\
\hline & & $\begin{array}{l}\text { a) Biomedical Sciences T/F (60 stems } \\
\text { in } 3 \text { hours, with allocation of the } \\
\text { sciences given) }\end{array}$ \\
\hline \multirow[t]{2}{*}{$\begin{array}{l}\text { SBA=Single Best } \\
\text { Answer type) }\end{array}$} & \multirow[t]{2}{*}{$\begin{array}{l}\text { SBA (20 in } 1 / 2 \text { hour): clinical } \\
\text { decision making }\end{array}$} & $\begin{array}{l}\text { b) General Medicine } \\
\text { i. T/F ( } 40 \text { stems in } 2 \text { hours, allocation } \\
\text { of finer specialties given) } \\
\text { ii. SBA ( } 30 \text { questions in } 1 \text { hour) on } \\
\text { clinical decision making }\end{array}$ \\
\hline & & Need $50 \%$ minimum in both papers \\
\hline \multirow[t]{2}{*}{$\begin{array}{l}\text { Objective Structured } \\
\text { Clinical Examination } \\
\text { (OSCE) }\end{array}$} & \multirow[t]{2}{*}{$\begin{array}{l}20 \times 3 \text { minute stations - } \\
\text { ECGs, radiographs, photos, } \\
\text { lab reports, communication skills }\end{array}$} & $\begin{array}{l}\text { Stations similar to MRCP (UK) PACES } \\
\text { examination with domain based assess- } \\
\text { ments, with emphasis on communication } \\
\text { skills. The } 7 \text { domains examined are given. }\end{array}$ \\
\hline & & $\begin{array}{l}12 \text { stations } \times 5 \text { minutes per station, } \\
\text { including a Basic and Advanced Life } \\
\text { Support (BALS) station that requires } \\
\text { mandatory pass }\end{array}$ \\
\hline
\end{tabular}

Table 3. General Medicine registrar training

\begin{tabular}{|c|c|c|}
\hline Component & Current training programme & Proposed training programme \\
\hline $\begin{array}{l}\text { General Medicine } \\
\text { training }\end{array}$ & $\begin{array}{l}18 \text { months hands-on full-time } \\
\text { training } \\
\text { Assessment - } \\
\text { RITA at } 6 \text { \& } 12 \text { months } \\
\text { Log Book }\end{array}$ & $\begin{array}{l}18 \text { months hands-on full-time training, } \\
\text { includes } 2 \text { weeks of General Medicine in a } \\
\text { non-teaching hospital } \\
\text { Assessment - } \\
\text { Workplace-based assessment (WBA); } \\
\text { RITA at } 6 \text { \& } 12 \text { months; } \\
\text { Portfolio assessment viva at } 18 \text { months }\end{array}$ \\
\hline \multirow[t]{2}{*}{ Formal teaching } & None & $\begin{array}{l}\text { Include time for IT, Ethics and Profes- } \\
\text { sionalism and Clinical Skills Training (A } \\
\text { series of courses to be conducted by the } \\
\text { PGIM for all trainees) } \\
\text { Add lectures or seminars on topics from } \\
\text { emerging sciences (e.g. climate change and } \\
\text { health) }\end{array}$ \\
\hline & & $\begin{array}{l}\text { Regional training centres to be established, } \\
\text { formalized and strengthened to deliver this. }\end{array}$ \\
\hline
\end{tabular}


Table 4. Finer specialties registrar training

\begin{tabular}{|c|c|c|}
\hline Component & Current training programme & Proposed training programme \\
\hline $\begin{array}{l}\text { Finer specialties: Total } \\
\text { duration }\end{array}$ & $(10 \times 2)+(5 \times 4)+(4 \times 2)=48$ weeks & 52 weeks \\
\hline $\begin{array}{l}\text { Cardiology and } \\
\text { Neurology }\end{array}$ & 10 weeks each & $\begin{array}{l}\text { Reduce to } 8 \text { weeks each with more } \\
\text { information being provided } \\
\text { (e.g. Objectives, web-based learning } \\
\text { material) } \\
\text { Include areas such as rehabilitation }\end{array}$ \\
\hline \multirow[t]{2}{*}{$\begin{array}{l}\text { Dermatology, } \\
\text { Psychiatry, } \\
\text { Rheumatology, and } \\
\text { Respiratory Medicine }\end{array}$} & 5 weeks each & $\begin{array}{l}\text { Reduce to } 4 \text { weeks each with more } \\
\text { information being provided } \\
\text { (e.g. Objectives, web-based learning } \\
\text { material) }\end{array}$ \\
\hline & & $\begin{array}{l}\text { Add } 4 \text { weeks each of Gastroenterology, } \\
\text { Endocrinology and Nephrology }\end{array}$ \\
\hline ICU: & 4 weeks & 2 weeks \\
\hline Elective & 4 weeks & $\begin{array}{l}2 \text { weeks, in one of specified areas, e.g., } \\
\text { Haematology, Oncology }\end{array}$ \\
\hline Assessment & $\begin{array}{l}\text { Log book } \\
\text { Case book of } 5 \text { cases }\end{array}$ & WBA added \\
\hline
\end{tabular}

Table 5. MD Examination

\begin{tabular}{|c|c|c|}
\hline Component & Current training programme & Proposed training programme \\
\hline Written component: & $\begin{array}{l}\text { - Essay ( } n=1,1 \text { hour) } \\
\text { - Case histories ( } n=5,75 \text { minutes) } \\
\text { - Data Interpretation ( } n=10,90 \text { minutes) } \\
\text { - Slides ( } n=20,1 \text { hour) } \\
\text { TOTAL = } 4 \text { hours and } 45 \text { minutes }\end{array}$ & $\begin{array}{l}\text { - Case Histories }(n=10) \text { and Data } \\
\text { Interpretation }(n=15) \text { in TWO papers } \\
\left(2 \frac{1}{2} \text { hours each) }\right. \\
\text { - } 5 \text { SEQs covering diverse areas (to be } \\
\text { blue printed) ( } 2 \text { hours) } \\
\text { - } 20 \text { Slides as separate paper } \\
\text { ( } 1 \text { hour) } \\
\text { TOTAL = } 7 \text { hours }\end{array}$ \\
\hline Long case & $\begin{array}{l}\text { One Long case } \\
\text { (60 minutes) }\end{array}$ & $\begin{array}{l}\text { One long case, } 45 \text { minutes with patient, } \\
30 \text { minutes with } 2 \text { examiners } \\
\text { (assessment is structured) }\end{array}$ \\
\hline
\end{tabular}




$\begin{array}{ll}\text { Short cases } & 5 \text { short cases } \\ \text { (Cardiovascular, Respiratory, } \\ \text { Neurological and Abdominal } \\ \text { Systems and Other) }\end{array}$

Viva
4 of 6 components

of which 2 are compulsory

(ie ethics and communication

skills and emergency medicine) a) Observed history taking (20 minutes) (examination findings given) to test data gathering skills

b) Communication skills (20 minutes) (examination findings given) to test decision making and communication skills

c) 5 Short case stations (cardiovascular, respiratory, neurological, abdomen, other systems, 10 minutes each)

a) To be standardised and structured

b) Altogether 40 minutes (in 2 panels of 2 examiners each)

c) Testing management of emergencies, ethical reasoning in clinical practice, knowledge of current literature and recent advances, and management of chronic diseases.

d) Written standardised scenarios given to candidates. Candidates will be tested using predetermined questions and the expected answers will be determined before the examination, with some flexibility allowed.

Table 6. General Medicine senior registrar training

\begin{tabular}{|c|c|c|}
\hline Component & Current training programme & Proposed training programme \\
\hline Local training & Research project & $\begin{array}{l}\text { Research or Audit to be commenced and } \\
\text { completed during Senior Registrar (SR) } \\
\text { training }\end{array}$ \\
\hline & Trainer's reports & $\begin{array}{l}\text { a) Training Objectives } \\
\text { b) Portfolio } \\
\text { c) Clear guidelines }\end{array}$ \\
\hline Foreign training & Trainer's reports & $\begin{array}{l}\text { a) Identify criteria for recognition of } \\
\text { training posts } \\
\text { b) Prepare for culture shock } \\
\text { c) Objectives } \\
\text { d) Clear guidelines } \\
\text { e) Portfolio required }\end{array}$ \\
\hline $\begin{array}{l}\text { Pre-Board } \\
\text { Certification } \\
\text { Assessment }\end{array}$ & None & $\begin{array}{l}\text { a) Viva } \\
\text { b) Clear guidelines } \\
\text { c) Portfolio-based (both at registrar } \\
\text { and SR level) }\end{array}$ \\
\hline
\end{tabular}




\section{Implications}

The new prospectus has several implications for trainers, trainees and other stakeholders. It attempts to explicitly define the role of the future physician, an exercise which should continuously evolve in collaboration with stakeholders such as the CCP. Some of the content areas resonate closely with undergraduate curriculums in the universities, and this should be encouraged as it aligns the future professional's learning from undergraduate years to specialization into a seamless continuum ${ }^{7}$. The attainment of all these outcomes has become a need in the profession and in the society for a long time, and this can only be achieved by broadening the scopes and strategies of both training and assessment (such as by introducing portfolios to promote lifelong learning and reflective practice, and workplace-based assessment to provide frequent feedback during training).

The emphases on basic science, clinical reasoning and judgement (including ethical reasoning), core clinical skills (including communication skills) and attitudes have been augmented at entry level, and detailed contents for the SEM have been identified and provided. Competence in basic and advanced life support is now mandatory at entry level.

The committee's proposal to the BOS on having a Professionalism Stream common to all postgraduate trainees was adopted and implemented by the PGIM. One of the most consistent comments during feedback from trainees was the need for a formal training program to augment the current in-service training. The BOS is currently in the process of identifying the structure and content of this program, and its implementation will need the recognition and strengthening by the PGIM of regional units (each teaching hospital or cluster to have its regional unit, consisting of its specialists in General Medicine and its specialties) and with the assistance of the professional colleges. The CCP is ideally placed to provide such support as well as help coordinate at national level such academic and professional training. The dominant roles played by the Royal Colleges in the UK and Australia in the training programs in their respective countries, and increasingly also in the global arena, are exemplary of this.

The non-teaching hospital appointment has been brought within the General Medicine appointment, so that it is implemented more realistically. New short appointments in Endocrinology, Gastroenterology and Nephrology have been added without lengthening the program. The elective appointment has been more formalized.

The newly expanded and structured WorkplaceBased Assessment (WBA) will provide much-needed formative assessment to trainees. This will include MiniClinical Evaluation Exercises, Case-Based Discussions,
Acute Care Assessment Tools, Directly Observed Procedural Skills and Multi-Source Feedback. Guidance to trainers for these was made available with the publication and distribution of a book. ${ }^{8}$

Portfolios for learning and assessment (one each for registrar and senior registrar levels, available online as annexes in the Prospectus) have been introduced, so that trainees' learning can be more holistic, reflective and monitored, and assessment more formative.

Trainer-training activities are a must to enable our trainers to implement these aspects effectively. All this further underpins the need for regional units and the CCP's support.

The MD examination retains its key feature of being an 'exit,' rather than 'entry,' examination. In this, the MD resonates more closely with the training programmes in Australasia than the MRCP (UK) PACES Examination. The latter is being marketed as a global standard for postgraduate examinations, but is an assessment of competence for entry to higher training ${ }^{9}$.

In the MD Examination, the assessments of clinical skills has been strengthened to include separate stations in communication skills and history-taking, similar to the MRCP (UK) PACES Examination - a much needed departure from the traditional 'short cases' and its focus on physical examination. These will provide opportunities to assess professionalism, empathy and bed-side manner, at least in a limited manner.

The long case has been retained as it is an excellent form of assessment on synthesis of knowledge necessary for the multi-morbidity and complex situations common to Sri Lankan clinical practice. ${ }^{10}$ The duration of examination has been increased to 30 minutes. Although several observed history-taking long cases or more structured formats of long cases are required to achieve the test reliability necessary for high-stake examinations ${ }^{11}$, logistical difficulties precluded the BOS from adopting this. The duration of the short cases too has been increased, and finer specialists will also become short case examiners in the future.

The senior registrar training has also been formalized, mostly in line with general PGIM trends and the introduction of WBAs and a portfolio. The Pre-Board Certification Assessment, another new PGIM requirement, has also been added.

The new Prospectus has incorporated the new requirements and trends in postgraduate medical education without lengthening the total duration of the program. Its effective implementation requires better engagement between trainers, trainees and the PGIM, 
and strengthening of regional training activities, including trainer-training. The BOS needs the support of the PGIM, trainers, trainees and the CCP to implement it, and this will doubtless become an ongoing, evolving experience for all. In the end, we hope that the hard work that has gone through and which will be required in the coming few years will be rewarded by our collective success in facing the challenges of the $21^{\text {st }}$ century.

\section{Members of the Prospectus Implementation Subcommittee: Professor Saroj Jayasinghe (chair-person), Dr. Panduka Karunanayake (convenor), Professor Saman Gunathilake, Professor Sisira Siribaddana, Dr. N. Tissera (retired), Dr. Harshini Fernando, Dr. Vajira Lekamwasam, Dr Shamila de Silva, Dr. T. Kumanan, Dr. Arjuna Medagama.}

Conflicts of interest: None.

\section{References}

1. Gunaratne M (1997). Lessons from history: the life of Prof. K. Rajasuriya (Inaugural Professor Kumaradasa Rajasuriya Oration). Journal of the Ceylon College of Physicians 30: 27-32.

2. PGIM website http://pgim.cmb.ac.lk/?page_id $=390$ accessed on 2017.02.01
3. Harden RM, Crosby JR, Davis MH (1999). An introduction to outcome-based education. Medical Teacher 21(1): 7-14.

4. Jason R, Frank JR, Linda S, Snell LS, Cate OT et al (2010). Competency-based medical education: theory to practice. Medical Teacher 32(8): 638-45.

5. Jayasinghe S (2015). Reforming a Conventional Medical Curriculum. Sarasavi Publications; Nugegoda.

6. Frenk J, Chen L, Bhutta ZA, Cohen J, Crisp N et al (2010). Health professionals for a new century: transforming education to strengthen health systems in an interdependent world. The Lancet 376(9756): 1923-958.

7. Jayasinghe S (2015). Key Topics for an Undergraduate Curriculum in General Medicine. Sarasavi Publications; Nugegoda.

8. Karunanayake P (2016). Workplace-Based Assessment in Medicine: An Introduction for Postgraduate Trainers in General Medicine and Its Specialties. Kumaran Book House; Colombo.

9. Website:http://www.mrcpuk.org/mrcpuk-examinations/ paces. (Accessed on 2017.02.03)

10. Jayasinghe S (2016). Describing complex clinical scenarios at the bedside: Is a systems science approach useful? Exploring a novel diagrammatic approach to facilitate clinical reasoning. BMC Medical Education 16: 264.

11. Wass V, de Vleuten CV, Shatzer J, Jones R (2001). Assessment of clinical competence. The Lancet 357: 945-49. 